\title{
COVID-19 in children: Should we be worried?
}

\author{
C L Hendricks, ${ }^{1}$ FCPaed (SA), MMed (Paediatrics and Child Health), Cert Clin Haematology (SA) Paed; R J Green, ${ }^{2} \mathrm{PhD}, \mathrm{DSc}$ \\ ${ }^{1}$ Department of Immunology, Institute for Cellular and Molecular Medicine and SAMRC Extramural Unit for Stem Cell Research and Therapy, \\ Faculty of Health Sciences, University of Pretoria, South Africa \\ ${ }^{2}$ Department of Paediatrics and Child Health, Steve Biko Academic Hospital and Faculty of Health Sciences, University of Pretoria, South Africa
}

Corresponding author: C L Hendricks (candice_hendricks@outlook.com)

\begin{abstract}
Reports indicate that children infected with SARS-CoV-2 have thus far presented with less severe disease than adults. Anxiety regarding a greater ability to transmit the virus is largely unfounded and has played a significant role in the decision to allow children to return to school. In some patients, however, especially in infants and in those with underlying comorbidities, severe disease must be anticipated and planned for accordingly. The most relevant severe clinical presentation in addition to the established respiratory complications, is that of a multisystem inflammatory disorder, with features resembling Kawasaki disease. The impact of the pandemic on the economic and social wellbeing of children, including food insecurity and care when parents are ill, cannot be ignored. During this pandemic, it is imperative to ensure access to routine and emergency medical services to sick children. In so doing, potentially devastating medical and socioeconomic consequences can be mitigated.
\end{abstract}

S Afr Med J 2020;110(9):864-868. https://doi.org/10.7196/SAMJ.2020.v110i9.15023

PubMed and other databases were thoroughly investigated using the search words 'COVID-19 and children'. The authors then evaluated published studies on the epidemiology, prevalence, transmission and diverse clinical presentations in children with COVID-19 from these sources.

Within a few months, COVID-19, caused by SARS-CoV-2, ${ }^{[1]}$ claimed the lives of 708036 people worldwide (6 August 2020). ${ }^{[2]}$ Entering the body through the respiratory mucosa and conjunctiva, the virus binds to the angiotensin-converting enzyme 2 (ACE2) present in the nasal passages, lung and intestines. ${ }^{[3]}$ ACE2 is responsible for converting angiotensin II into angiotensin (1-7) in the reninangiotensin-aldosterone system (RAAS) for blood pressure control. ${ }^{[4]}$ The resulting excessive accumulation of angiotensin II results in vasoconstriction, inflammation and fibrosis. ${ }^{[4,5]}$

Viral entry into cells induces a protective immune response in some people ${ }^{[6]}$ while in others a 'cytokine storm', referring to massive release of pro-inflammatory cytokines, ensues. ${ }^{[7]}$ This cytokine storm causes tissue damage and the clinical picture of acute respiratory distress syndrome (ARDS), the leading cause of COVID-19-related deaths, ${ }^{[7]}$ in patients unable to contain the infection.

Throughout the development and establishment of this pandemic, children have certainly been reported to be infected from the start, ${ }^{[8]}$ but have been noted to have less severe disease than adults. The incidence has consistently been reported as $1-5 \% \cdot{ }^{[9-12]}$ Some of the paediatric reports from China, Italy and the USA are summarised in Table 1. These indicate that COVID-19 remains a less dangerous disease in children, most transmission in children is through family members, fever and respiratory symptoms occur most frequently and very few patients develop critical disease.

Much information affecting the paediatric population, however, remains elusive, which provides the backdrop against which conflicting reports cause confusion and fear. As the disease has evolved, many more pertinent questions related to children have been raised: Can the virus be contracted through intrauterine spread? Can children go to school? What is the actual risk of severe disease? What is the economic impact of COVID-19 in children? Some of these questions are addressed below.

\section{Why do children have less severe disease than adults? \\ Possible explanations are:}

- Qualitative differences in response: Children are known to have diminished innate and adaptive immune responses, which lead to decreased cytokine responses, especially in neonates, compared with adults. ${ }^{[13]}$ They may therefore mount a blunted immune response ${ }^{[14,15]}$ or respond differently to adults. ${ }^{[9,16]}$

- Receptor: Children are thought to possess less mature and therefore less functional forms of the ACE2 receptor, the primary SARS$\mathrm{CoV}-2$ receptor, as described above. ${ }^{[9,17]}$ A recently published retrospective review examining the expression of ACE2 in the nasal epithelium of a previous cohort of patients (who had been enrolled to detect nasal biomarkers of asthma), found significantly lower levels of ACE2 in children $<10$ years old. ${ }^{[18]}$ This finding may decrease the ability to acquire SARS-CoV-2 infection in the nasal epithelium, ${ }^{[4]}$ but does not necessarily relate to decreased expression in the lung epithelium, as gene expression in these two areas differs. ${ }^{[18]}$ Recently, the cluster of differentiation 147 (CD147) has also been shown to act as a receptor for SARS-CoV-2 in T-cell lines and cells of epithelial origin. ${ }^{[19]} \mathrm{CD} 147$, interestingly, is also the putative receptor for HIV-1, measles and malaria merozoites entry into erythrocytes. The expression analysis demonstrated high CD147 gene expression in children of black African origin compared with white adolescents and adults. Whether this will reflect in an increased risk of infection in black African children is currently not known.

- Competition with other viruses: Children usually have many viruses lining their respiratory tracts and COVID-19 may be competing for engagement with receptors in this regard. ${ }^{[16]}$ The presence of other viruses may also mean that high antibody levels against viruses are present. ${ }^{[9]}$

- Recent bacillus Calmette-Guérin (BCG) vaccine: Association studies have suggested that the routine BCG vaccine, administered at birth, may help to protect from SARS-CoV-2 infection as a result of 'trained innate immunity.'[20] Children who have recently been vaccinated may have greater protection. 
Table 1. Summary of paediatric reports

\begin{tabular}{|c|c|c|c|c|c|c|}
\hline Report origin & Report date & Cohort, $n$ & Transmission, \% & Clinical signs & Incidence of severity, \% & $\begin{array}{l}\text { Mortality rate } \\
\text { (at time of } \\
\text { publication), \%* }\end{array}$ \\
\hline China $^{[9]}$ & 25 March 2020 & 728 & Not reported & $\begin{array}{l}\text { Fever, respiratory } \\
\text { symptoms }\end{array}$ & $\begin{array}{l}\text { Asymptomatic, } 12.9 \\
\text { (severe/critical, 2.9) }\end{array}$ & $\begin{array}{l}n=1 \text { (not reported } \\
\text { whether SARS- } \\
\text { CoV- } 2 \text { confirmed) }\end{array}$ \\
\hline China $^{[12]}$ & 25 April 2020 & 36 & Family, 89 & Fever, cough & $\begin{array}{l}\text { Asymptomatic, } 28 \\
\text { (severe/critical, 0) }\end{array}$ & 0 \\
\hline $\mathrm{USA}^{[10]}$ & 10 April 2020 & $2572^{\dagger}$ & $\begin{array}{l}\text { Home or } \\
\text { community, } 91\end{array}$ & Fever, cough, SOB & $\begin{array}{l}\text { Asymptomatic cases } \\
\text { unknown } \\
\text { Hospitalisations, } 5.7-20^{\ddagger} \\
\text { (severe/critical, } 0.58-2.00 \text { ) }\end{array}$ & $0.001(n=3)$ \\
\hline China $^{[21]}$ & 23 April 2020 & 171 & Family, 90 & $\begin{array}{l}\text { Fever, cough, } \\
\text { pharyngeal erythema }\end{array}$ & $\begin{array}{l}\text { Asymptomatic, } 15.8 \\
\text { Rate of hospitalisation not } \\
\text { provided } \\
\text { (severe/critical, 1.8) }\end{array}$ & $0.005(n=1)$ \\
\hline Italy $^{[11]}$ & 1 May 2020 & 100 & $\begin{array}{l}\text { Outside family/ } \\
\text { unknown, } 55\end{array}$ & Fever, cough, SOB & $\begin{array}{l}\text { Asymptomatic, } 21 \\
\text { Hospitalisations, } 38 \\
(\text { severe/critical, } 2)^{\varsigma}\end{array}$ & 0 \\
\hline $\mathrm{USA}^{[22]}$ & 6 May 2020 & 177 & Not reported & Fever, cough, SOB & $\begin{array}{l}\text { Asymptomatic infections } \\
\text { not provided } \\
\text { Hospitalisations, } 25 \\
\text { (severe/critical, 5) }\end{array}$ & 0 \\
\hline China $^{[23]}$ & 3 June 2020 & 157 & Not reported & Fever, cough & $\begin{array}{l}\text { Asymptomatic, } 30 \\
\text { Hospitalised cohort, } 100 \\
\text { (severe/critical, 5.7) }\end{array}$ & 0.01 \\
\hline
\end{tabular}

\section{Transmission of the virus by children}

Reports indicate that asymptomatic disease, ${ }^{[9,11,12]}$ mild disease in the presence of persistently positive SARS-CoV-2 polymerase chain reaction (PCR) results, ${ }^{[14]}$ and viral shedding in the stool, ${ }^{[14,24]}$ can be seen in children. Children can therefore potentially transmit the virus through respiratory secretions, as well as through faecal-oral spread. However, early reports from China suggesting that children may be the primary source of spread of SARS-CoV-2, resembling transmission characteristics of influenza, have not proven to be true. ${ }^{[25]}$ In countries with widespread community testing, such as South Korea and Iceland, with adequate contact tracing, children were found to be significantly under-represented. In population screening in Iceland, no children $<10$ years of age were found to be positive for SARSCoV-2 compared with $0.8 \%$ of the general population, ${ }^{[26]}$ and in Vo, Italy, no children $<10$ years were found to be positive, compared with $2.6 \%$ of the general population. ${ }^{[27]}$

Evidence from contact tracing in Japan found lower attack rates in children, ${ }^{[28]}$ and a study in Guangzhou, China, found a much lower secondary attack rate for children than adults (odds ratio (OR) 0.23). ${ }^{[29]}$ In a study in the Netherlands, no child $<19$ years of age could be traced as a source of infection in an adult. ${ }^{[30]}$

These facts have a bearing on continued 'lockdown', especially of children, and the number of unintended collateral damage consequences they experience.

\section{Severe clinical presentations}

Although children rarely progress to severe disease, the potential does exist and multiple reports of severe disease have been published. Apart from the respiratory complications that are well described, small cohorts of children in Europe, the UK ${ }^{[31]}$ and the USA ${ }^{[32]}$ were found to present with a widespread inflammatory syndrome, resembling atypical Kawasaki disease or toxic shock syndrome. Kawasaki disease refers to a very rare disorder of unknown cause, ${ }^{[33]}$ synonymous with mucocutaneous lymph node syndrome. ${ }^{[34]}$ Patients present with a combination of features, such as an unrelenting fever for $>5$ days with mucocutaneous manifestations (conjunctivitis, changes in the tongue or oral cavity, oedema of the hands and feet followed by desquamation, a rash and cervical lymph node involvement). ${ }^{[34]}$ The cardiac manifestations are related to a microvasculitis leading to aneurysms of the coronary arteries in up to $20 \%$ of affected patients, although other arteries in the body may also be affected. ${ }^{[34]}$

Children with COVID-19 may present with some, but not all of these features. Further evidence for the association was an initial review of 10 cases of the Kawasaki-like disease in Italy, which revealed a 30 -fold increase in such cases in the COVID-19 era compared with the 5 years preceding COVID-19. ${ }^{[33]}$ The majority of these children had positive serological testing for SARS-CoV-2 and not PCR. This indicates that primary infection is not the cause and suggests that host immune response against the virus is the driving pathogenesis. ${ }^{[33,35,36]}$ Further cohorts have included patients from the USA ( 3 reports: $n=17,{ }^{[37]} n=95,{ }^{[38]}$ and $n=186^{[39]}$ ), France (2 reports: $n=21^{[40]}$ and $n=16^{[41]}$ ) and the UK ( 2 reports: $n=8^{[27]}$ and $n=58^{[42]}$ ). Although a large proportion of these patients required intensive care, the literature indicates that outcomes are very encouraging, with a mortality rate of $2-4 \%{ }^{[36]}$

In this regard, the Royal College of Paediatrics and Child Health (RCPCH) refers to 'Paediatric multi-system inflammatory syndrome potentially associated with COVID-19'. A case definition has been 
formulated by this society to assist with treating such patients, summarised in Table $2 .{ }^{[43]}$ Following on from these cases, the Centers for Disease Control and Prevention (CDC) has also provided a name for and definition of the illness (Table 3) ${ }^{[44]}$ Both definitions include severely ill patients only, and possible risk, excluding patients who present with milder disease. ${ }^{[36]}$

Patients presenting with this condition have to be referred for specialist care in a high-care or intensive care setting for treatment. Medical management has included immunoglobulins, corticosteroids and aspirin; however, clinical trials will determine the optimum treatment algorithm. All medical personnel are urged to have a high index of suspicion in all patients with possible SARS-CoV-2 exposure to ensure prompt treatment.

\section{Intrauterine spread}

The first infected neonate, diagnosed soon after birth, was reported from China in February 2020 $0^{[45]}$ and has been the catalyst for the determination of whether the virus is able to cross the placenta. Chen et al. ${ }^{[46]}$ reported negative SARS-CoV-2 PCR results from amniotic fluid, cord blood and neonatal throat swabs from 6 pregnant patients who tested positive for SARS-CoV-2. The small sample size and the enrolment of mothers while in the third trimester are important confounders. These findings are supported by Li et al., ${ }^{[47]}$ where serial sampling in an exposed neonate, including urine, faeces and blood, showed persistent absence of SARS-CoV-2, and a further cohort of 10 neonates from infected mothers also tested negative. ${ }^{[48]}$ On the other side of the spectrum, SARS-CoV-2 RNA has been found on the fetal side of the placenta in 2 COVID-19-positive mothers in whom the infants also tested positive, as well as from placental swabs from COVID-19-positive mothers in whom the infants tested negative. ${ }^{[49]}$ These findings suggest that the potential for intrauterine spread does exist. This argument is further strengthened by the presence of virus-specific IgM in 2 neonates from COVID-19positive mothers. ${ }^{[50]}$ In spite of these reports, no definitive evidence for intrauterine spread has been found and there is currently no consensus on the subject. It has been imperative to implement measures to optimise deliveries, especially in very ill hypoxic mothers where there is an increased risk of hypoxia in the neonate. ${ }^{[48]}$ To this end, an expert consensus document has been published for the management of mothers and their infants in this special risk group. ${ }^{[51]}$

\section{High-risk populations}

Children $<1$ year of age have been found to have higher hospital and intensive care unit (ICU) admission rates than older children, ${ }^{[10,11]}$ in keeping with their immature immune response. ${ }^{[13]}$ Furthermore, other potentially vulnerable groups include children with underlying immune deficiencies (congenital, secondary to malignancy or administration of chemotherapy/radiation therapy, after transplantation, patients on high doses of glucocorticoids), underlying lung diseases (e.g. asthma), cardiovascular diseases, chronic kidney disease, diabetes mellitus and obesity. ${ }^{[22]}$ Many reports have indicated that in children progressing to severe disease, a high proportion had underlying diseases, ${ }^{[10,11,53]}$ and $83 \%$ of those admitted to ICUs in the USA were found to have comorbidities. ${ }^{[1]}$ The mortality rate in the latter cohort was $<5 \%$, which is much lower than that reported in critically ill adults.

In spite of these reports, the UK National Institute for Health and Care Excellence (NICE) has advised that immunocompromised children and adolescents do not possess a higher risk of infection with SARS-CoV-2, but that direct face-to-face contact should nonetheless be avoided wherever possible. ${ }^{[54]}$ A small cohort of SARS-CoV-2positive patients with underlying kidney disease managed with immunosuppressive therapy was recently found to present with mild disease, with no patients requiring ICU admission. Echoing these sentiments was a report from Lombardy, Italy, where 5 paediatric oncology patients presented with self-limiting disease. ${ }^{[55]}$ Whether these reports will hold true in the months to come remains to be seen, but nonetheless, social distancing, hand washing and other strict infection control measures (as with all patients) must remain a priority, while ensuring that patients are able to access essential medication.

\section{Should children go to school?}

After the initial strict lockdown in South Africa (SA), conversations regarding the safety of returning to school have sparked controversy, as fears of rapid viral spread were brought to light. Continued

Table 2. RCPCH case definition of paediatric multisystem inflammatory syndrome potentially associated with COVID-19

- A child presenting with persistent fever, inflammation (neutrophilia, elevated CRP and lymphopenia) and evidence of single- or multiorgan dysfunction (shock, cardiac, respiratory, renal, gastrointestinal or neurological disorder) with additional features (full list supplied by $\mathrm{RCPCH}),{ }^{[43]}$ which may include children fulfilling full or partial criteria for Kawasaki disease

- Exclusion of any other microbial cause, including bacterial sepsis, staphylococcal or streptococcal shock syndromes, infections associated with myocarditis such as enterovirus (waiting for results of these investigations should not delay seeking expert advice)

- SARS-CoV-2 PCR testing may be positive or negative

RCPCH = Royal College of Paediatrics and Child Health; CRP = C-reactive protein.

\section{Table 3. CDC case definition for multisystem inflammatory syndrome in children}

- A patient aged $<21$ years presenting with fever, ${ }^{*}$ laboratory evidence of inflammation, ${ }^{\dagger}$ and evidence of clinically severe illness requiring hospitalisation, with multisystem $(\geq 2)$ organ involvement (cardiac, renal, respiratory, haematological, gastrointestinal, dermatological or neurological); and

- No alternative plausible diagnoses; and

- Positive for current or recent SARS-CoV-2 infection by RT-PCR, serology or antigen test; or COVID-19 exposure within the 4 weeks prior to the onset of symptoms

$\mathrm{CDC}=$ Centers for Disease Control and Prevention; RT-PCR $=$ reverse transcription polymerase chain reaction

Fever $\geq 38.0^{\circ} \mathrm{C}$ for $\geq 24$ hours, or subjective fever lasting $\geq 24$ hours.

interleukin 6, elevated neutrophils, reduced lymphocytes and low albumin. 
school closure has, however, been found to not only have economic consequences but also psychological consequences for the child. ${ }^{[56]}$ Based on the evidence in the literature, the SA Paediatric Association (SAPA) issued a statement, advocating for the return of children to school. ${ }^{[57]}$ The statement also provides guidelines for the implementation of learning practices, while minimising infection risk. Particular emphasis is placed on the benefit for poor children, who not only have no or limited access to online learning but who additionally benefit from school feeding schemes. As significant inequalities exist in the SA schooling system in terms of resources, schools in underresourced areas will have to be provided with the necessary support to ensure a safe school environment.

\section{Face masks}

According to the CDC, face masks are not recommended for children $<2$ years old, because the risk of suffocation is higher in younger children. ${ }^{[58]}$ The SAPA position statement on the return of children to school has advised that masks should be used by children $>4$ years of age in a school setting.

\section{Collateral damage to children}

In a time of fear and anxiety, medical management of sick children should remain pragmatic and evidence based. Sick children, presenting with fever and cough, are being treated with empirical antibiotics, hydroxychloroquine and azithromycin by healthcare practitioners, even for mild and unproven COVID-19. These treatment interventions are not benign in children and lead to sideeffects, antibiotic resistance and dysbiosis of the human microbiome. ${ }^{[59]}$ Hydroxychloroquine and azithromycin have no proven benefit in COVID-19 - certainly not in children. ${ }^{[60]}$

Moreover, 'lockdown' has had unintended economic and social consequences for children. Children with acute and chronic conditions are prevented from accessing healthcare, leading to loss of routine immunisation opportunities, access to chronic medication and loss of feeding opportunities that are frequently provided at schools ${ }^{[59]}$ Food insecurity, leading to an increase in malnutrition, is a very real concern, as is the potential lack of care in homes where parents become ill and require hospitalisation.

\section{The South African situation}

On 6 August 2020, SA had 529877 cases and 9298 deaths related to COVID-19. ${ }^{[61]}$ The latest report detailing the age breakdown of deaths on 22 June 2020, confirmed that 8 deaths occurred in patients $<19$ years of age ( 3 were $<9$ years old). ${ }^{[62]}$ As anticipated, the numbers are increasing rapidly and the full extent of the SA situation, including the risks in children, will only unfold in the coming months. Western Cape Province, which was the initial epicentre of the disease in SA, recorded $>1000$ children $<6$ years of age with COVID-19 on 6 August 2020. ${ }^{[63]}$ Cases of paediatric multisystem inflammatory syndrome (PMIS) have also been recorded.

Although we may feel secure as international reports indicate a decreased risk of severe disease in children, SA has many unique factors to consider. The majority of our population is of black African ancestry. In the UK and USA, black African people (as well as other minorities) have been disproportionately affected by the pandemic. ${ }^{[6,65]}$ Comorbidities and the comparatively low socioeconomic status of these persons are thought to put them at higher risk of disease, similar to our SA situation. Whether differential host immune responses are at play will need to be determined in future. In 2017, $\sim 65 \%$ of SA children lived below the poverty line; ${ }^{[6]]}$ they also suffer disproportionately from malnutrition, gastroenteritis and communicable diseases. Furthermore, SA has the highest burden of HIV and tuberculosis in the world. ${ }^{[67]}$ Even though significant progress has been made in the prevention of mother-to-child transmission (PMTCT), down to $1.1 \%^{[68]}$ in $2015-2016,260000$ children $<14$ years of age were reported to be living with $\mathrm{HIV}^{[67]}$ in 2018. The clinical risks of COVID-19 must therefore be discussed in conjunction with the impact of the virus on other diseases. A report from China showed a marked reduction in paediatric outpatient visits compared with the year prior to COVID-19. ${ }^{[69]}$ This trend has also been observed in SA and can have far-reaching public health consequences if measures are not put in place to mitigate the risk. According to Lancet Global Health ${ }^{[70]}$ potentially 1.2 million additional child deaths have been estimated to occur secondary to disruption of essential medical services in low- and middle-income countries. This alarming figure calls to action the need to prioritise maternal and newborn care, preventive healthcare, such as immunisations, and food security for all vulnerable families. ${ }^{[0]}$

Declaration. None.

\section{Acknowledgements. None.}

Author contributions. Both authors contributed equally to the development of the manuscript.

Funding. None.

Conflicts of interest. None.

1. Shekerdemian LS, Mahmood NR, Wolfe KK, et al. Characteristics and outcomes of children with coronavirus disease 2019 (COVID-19) infection admitted to US and Canadian pediatric intensive care units. JAMA Pediatr 2020;2019:1-6. https://doi.org/10.1001/jamapediatrics.2020.1948

2. John Hopkins University and Medicine. COVID-19 map - Johns Hopkins Coronavirus Resource Center. https://coronavirus.jhu.edu/map.html (accessed 6 August 2020).

3. Mulvey JJ, Magro CM, Ma LX, Nuovo GJ, Baergen RN. Analysis of complement deposition and viral RNA in placentas of COVID-19 patients. Ann Diagn Pathol 2020;46:151530. https://doi.org/10.1016/j. anndiagpath.2020.151530

4. Patel AB, Verma A. Nasal ACE2 levels and COVID-19 in children. JAMA 2020;323(23):2386-2387. https://doi.org/10.1001/jama.2020.8946

5irano T, Murakami M. COVID-19: A new virus, but a familiar receptor and cytokine release syndrome. Immunity 2020:52(5):731-733. https://doi.org/10.1016/j.immuni.2020.04.003

6. Shi Y, Wang Y, Shao C, et al. COVID-19 infection: The perspectives on immune responses. Cell Death Differ 2020;27(5):1451-1454. https://doi.org/10.1038/s41418-020-0530-3

7i X, Geng M, Peng Y, Meng L, Lu S. Molecular immune pathogenesis and diagnosis of COVID-19. . Li X, Geng M, Peng Y, Meng L, Lu S. Molecular immune pathogenesis and di
J Pharm Anal 2020;10(2):102-108. https://doi.org/10.1016/j.jpha.2020.03.001

8. Liu W, Zhang Q, Chen J, et al. Detection of Covid-19 in children in early January 2020 in Wuhan, 8. Liu W, Zhang Q, Chen J, et al. Detection of Covid-19 in children in early January 2020
China. N Engl J Med 2020;382(14):1370-1371. https://doi.org/10.1056/NEJMc2003717

9. Dong Y, Mo X, Hu Y, et al. Epidemiology of COVID-19 among children in China. Pediatrics Dong Y, Mo X, Hu Y, et al. Epidemiology of COVID-19 an
2020;145(6):e20200702. https://doi.org/10.1542/peds.2020-0702

10. Bialek S, Gierke R, Hughes M, McNamara LA, Pilishvili T, Skoff T. Coronavirus disease 2019 in children United States, February 12 - April 2, 2020. MMWR Morb Mortal Wkly Rep 2020;69(14):422-426. https://doi.org/10.15585/mmwr.mm6914e4

11. Parri N, Lenge M, Buonsenso D. Coronavirus infection in pediatric emergency departments (CONFIDENCE) research group. Children with Covid-19 in pediatric emergency departments in Italy. N Engl J Med 2020;383(2):187-190. https://doi.org/10.1056/NEJMc2007617

12. Qiu H, Wu J, Hong L, Luo Y, Song Q, Chen D. Clinical and epidemiological features of 36 children with coronavirus disease 2019 (COVID-19) in Zhejiang, China: An observational cohort study. Lancet Infect Dis 2020;20(6):689-696. https://doi.org/10.1016/S1473-3099(20)30198-5

13. Simon AK, Hollander GA, McMichael A. Evolution of the immune system in humans from infancy to 3imon AK, Hollander GA, McMichael A. Evolution of the immune system in humans from
old age. Proc R Soc B Biol Sci 2015;282(1821):1-9. https://doi.org/10.1098/rspb.2014.3085

old age. Proc R Soc B Biol Sci 2015;282(1821):1-9. https://doi.org/10.1098/rspb.2014.3085
14. Kam K, Yung CF, Cui L, et al. A well infant with coronavirus disease 2019 with high viral load. Clin 4. Kam K, Yung CF, Cui L, et al. A well infant with coronavirus disease 2019 with
Infect Dis 2020;71(15):847849. https://doi.org/10.1093/cid/ciaa201/5766416

15. Hong H, Wang Y, Chung HT, Chen CJ. Clinical characteristics of novel coronavirus disease 2019 5ong H, Wang Y, Chung HT, Chen CJ. Clinical characteristics of novel coronavirus disease 2019
(COVID-19) in newborns, infants and children. Pediatr Neonatol 2020;61(2):131-132. https://doi. org/10.1016/j.pedneo.2020.03.001

16. Brodin P. Why is COVID-19 so mild in children? Acta Paediatr 2020;109(6):1082-1083. https://doi. org/10.1111/apa.15271

17. Ludvigsson JF. Systematic review of COVID-19 in children shows milder cases and a better prognosis than adults. Acta Paediatr 2020;109(6):1088-1095. https://doi.org/10.1111/apa.15270

18. Bunyavanich S, Do A, Vicencio A. Nasal gene expression of angiotensin-converting enzyme 2 in children and adults. JAMA 2020;323(23):2427. https://doi.org/10.1001/jama.2020.8707

19. Radzikowska U, Ding M, Tan G, et al. Distribution of ACE2, CD147, CD26 and other SARS-CoV-2 associated molecules in tissues and immune cells in health and in asthma, COPD, obesity, hypertension, and COVID-19 risk factors. Allergy 2020:1-37. https://doi.org/10.1111/all.14429

20. O'Neill LAJ, Netea MG. BCG-induced trained immunity: Can it offer protection against COVID-19? O'Neill LAJ, Netea MG. BCG-induced trained immunity: Can it offer protection ag
Nat Rev Immunol 2020;20(6):335-337. https://doi.org/10.1038/s41577-020-0337-y

21. Lu X, Zhang L, Du H, et al. SARS-CoV-2 infection in children. N Engl J Med 2020;382(17):1663-1665. hu X, Zhang L, Du H, et al. SARS-CoV-2

22. DeBiasi RL, Song X, Delaney M, et al. Severe COVID-19 in children and young adults in the Washington, DC Metropolitan Region. J Pediatr 2020;223:199-203. https://doi.org/10.1016/j. jpeds.2020.05.007 
23. Wu H, Zhu H, Yuan C, et al. Clinical and immune features of hospitalized pediatric patients with coronavirus disease 2019 (COVID-19) in Wuhan, China. JAMA Netw Open 2020;3(6):1-10. https:// doi.org/10.1001/jamanetworkopen.2020.10895

24. Cui Y, Tian M, Huang D, et al. A 55-day-old female infant infected with 2019 novel coronavirus disease: Presenting with pneumonia, liver injury, and heart damage. J Infect Dis 2020;221(11):1775-1781. https:// doi.org/10.1093/infdis/jiaal13

25. Munro APS, Faust SN. Children are not COVID-19 super spreaders: Time to go back to school. Arch Dis Child 2020;105(7):618-619. https://doi.org/10.1136/archdischild-2020-319474

26. Gudbjartsson DF, Helgason A, Jonsson $\mathrm{H}$, et al. Spread of SARS-CoV-2 in the Icelandic population. N Engl J Med 2020;382(24):2302-2315. https://doi.org/10.1056/NEJMoa2006100

27. Lavezzo E, Franchin E, Ciavarella C, et al. Suppression of COVID-19 outbreak in the municipality of Vo, Italy. medRxiv 2020:1-23. https://doi.org/10.1101/2020.04.17.20053157

28. Mizumoto K, Omori R, Nishiura H. Age specificity of cases and attack rate of novel coronavirus disease (COVID-19). medRxiv 2020:1-6. https://doi.org/10.1101/2020.03.09.20033142

29. Jing Q-L, Liu M-J, Yuan J, et al. Household secondary attack rate of COVID-19 and associated determinants. medRxiv 20201:22. https://doi.org/10.1101/2020.04.11.20056010

30. National Institute for Public Health and the Environment. Ministry of Health, Welfare and Sport: Children and COVID-19, 2020. https://www.rivm.nl/en/novel-coronavirus-covid-19/children-andcovid-19 (accessed 6 June 2020).

31. Riphagen S, Gomez X, Gonzalez-Martinez C, Wilkinson N, Theocharis P. Hyperinflammatory shock

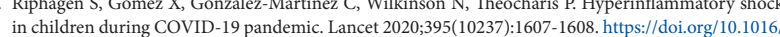
in children during COVID-1
S0140-6736(20)31094-1

32. Fliesler N. A new pediatric inflammatory syndrome linked to COVID-19 - Boston children's discoveries. https://discoveries.childrenshospital.org/covid-19-inflammatory-syndrome-children/ (accessed 12 May 2020)

33. Verdoni L, Mazza A, Gervasoni A, et al. An outbreak of severe Kawasaki-like disease at the Italian epicentre of the SARS-CoV-2 epidemic: An observational cohort study. Lancet 2020;6736(20):1-8. https://doi.org/10.1016/S0140-6736(20)31103-X

34. Park M. Pediatric cardiology for practitioners. In: Park MK, ed. Kawasaki Disease. 5th ed. Philadelphia, USA: Mosby, 2008:453-464.

35. Viner RM, Whittaker E. Kawasaki-like disease: Emerging complication during the COVID-19 pandemic. Lancet 2020;6736(20):19-20. https://doi.org/10.1016/S0140-6736(20)31129-6

36. Levin M. Childhood multisystem inflammatory syndrome - a new challenge in the pandemic. N Engl J Med 2020;383(4):393-395. https://doi.org/10.1056/NEJMe2023158

37. Cheung EW, Zachariah P, Gorelik M, et al. Multisystem inflammatory syndrome related to COVID-19 in previously healthy children and adolescents in New York City. JAMA 2020;324(3):294. https://doi. org $/ 10.1001 /$ jama.2020.10374

38. Dufort EM, Koumans EH, Chow EJ, et al. Multisystem inflammatory syndrome in children in New York State. N Engl J Med 2020;383(4):347-358. https://doi.org/10.1056/NEJMoa2021756

39. Feldstein LR, Rose EB, Horwitz SM, et al. Multisystem inflammatory syndrome in US children and . Feldstein LR, Rose EB, Horwitz SM, et al. Multisystem inflammatory syndrome in US child
adolescents. N Engl J Med 2020;383(4):334-346. http://doi.org/10.1056/NEJMoa202168040

40. Toubiana J, Poirault $\mathrm{C}$, Corsia A, et al. Kawasaki-like multisystem inflammatory syndrome in childre during the covid-19 pandemic in Paris, France: Prospective observational study. BMJ 2020;369:1-7. https://doi.org/10.1136/bmj.m209

41. Pouletty M, Borocco C, Ouldali N, et al. Paediatric multisystem inflammatory syndrome temporally associated with SARS-CoV-2 mimicking Kawasaki disease (Kawa-COVID-19): A multicentre cohort. Ann Rheum Dis 2020;79(8):999-1006. https://doi.org/10.1136/annrheumdis-2020-217960

42. Whittaker E, Bamford A, Kenny J, et al. Clinical characteristics of 58 children with a pediatric inflammatory multisystem syndrome temporally associated with SARS-CoV-2. JAMA 2020;324(3):259. https://doi.org/10.1001/jama.2020.10369

43. Royal College of Paediatrics and Child Health. Guidance: Paediatric multisystem inflammatory syndrome temporally associated with COVID-19. 2020. https://www.rcpch.ac.uk/sites/default/ files/2020-05/COVID-19-Paediatric-multisystem-inflammatorysyndrome-20200501.pdf (accessed 30 May 2020).

44. Centers for Disease Control and Prevention. Multisystem inflammatory syndrome in children (MIS-C) associated with coronavirus disease 2019 (COVID-19). 2020. https://emergency.cdc.gov/ han/2020/han00432.asp?deliveryName=USCDC_511-DM28431 (accessed 14 May 2020).

45. Wang S, Guo L, Chen L, et al. A case report of neonatal 2019 coronavirus disease in China. Clin Infect Dis 2020:3-7. https://doi.org/10.1093/cid/ciaa225/5803274

46. Chen $\mathrm{H}$, Guo J, Wang C, et al. Clinical characteristics and intrauterine vertical transmission potential of COVID-19 infection in nine pregnant women: A retrospective review of medical records. Lancet 2020;395(10226):809-815. https://doi.org/10.1016/S0140-6736(20)30360-3 47. Li Y, Zhao R, Zheng S, et al. Lack of vertical transmission of severe acute respiratory syndrome 48. Zhu H, Wang L, Fang C, et al. Clinical analysis of 10 neonates born to mothers with 2019-nCoV pneumonia. Transl Pediatr 2020;9(1):51-60. https://doi.org/10.21037/tp.2020.02.06

49. Penfield CA, Brubaker SG, Limaye MA, et al. Detection of severe acute respiratory syndrome

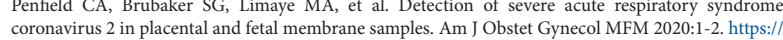
doi.org/10.1016/j.ajogmf.2020.100133

50. Zeng H, Xu C, Fan J, et al. Antibodies in infants born to mothers with COVID-19 pneumonia. JAMA 2020;323(18):1848-1849. https://doi.org/10.1001/jama.2020.4861

51. Chen D, Yang H, Cao Y, et al. Expert consensus for managing pregnant women and neonates born to mothers with suspected or confirmed novel coronavirus (COVID-19) infection. Int J Gynecol Obste 2020;149(2):130-136. https://doi.org/doi.org/10.1016/S0140-6736(20)30360-3

52. Edwards M. Coronavirus disease 2019 (COVID-19): Considerations in children. UpToDate 2020:1-32 53. Xia W, Shao J, Guo Y, Peng X, Li Z, Hu D. Clinical and CT features in pediatric patients with COVID-19 infection: Different points from adults. Pediatr Pulmonol 2020;55(5):1169-1174. https:/ doi.org/10.1002/ppul.24718

4. Wise J. Covid-19 is no worse in immunocompromised children, says NICE. BMJ 2020;369:m1802 https://doi.org/10.1136/bmj.m1802

55. Balduzzi A, Brivio E, Rovelli A, et al. Lessons after the early management of the COVID-19 outbreak in a pediatric transplant and hemato-oncology center embedded within a COVID-19 dedicated hospital in Lombardia, Italy. Estote parati. Bone Marrow Transplant 2020:1-6. https://doi.org/10.1038/s41409020-0895-4

56. Viner RM, Russell SJ, Croker H, et al. School closure and management practices during coronavirus outbreaks including COVID-19: A rapid systematic review. Lancet Child Adolesc Health 2020;4(5):397-404. https://doi.org/doi.org/10.1016/S2352-4642(20)30095-X

57. South African Paediatric Association Position Statement: Return of South African children to school. 2020. https://wcedonline.westerncape.gov.za/documents/BackToSchool/SAPA\%20School\%20Return\%20 Position\%20Statement.pdf (accessed 5 August 2020).

58. Centers for Disease Control and Prevention. Use cloth face coverings to help slow spread. 2020. https:// www.cdc.gov/coronavirus/2019-ncov/prevent-getting-sick/diy-cloth-face-coverings.html (accessed 5 August 2020).

59. Van Bruwaene L, Mustafa F, Cloete J, Ameena G, Green RJ. What are we doing to the children of South Africa under the guise of COVID-19 lockdown? S Afr Med J 2020;110(7):574-575. https://doi. org/10.7196/SAMJ.2020.v110i7.14932

60. Gautret P, Lagier J-C, Parola P, et al. Hydroxychloroquine and azithromycin as a treatment of COVID-19: Results of an open-label non-randomized clinical trial. Int J Antimicrob Agents 2020:56(1):1-24. https://doi.org/10.1016/i.ijantimicag.2020.105949

61. National Institute of Communicable Diseases. COVID-19 surveillance. 2020. https://www.nicd.ac.za/ (accessed 6 August 2020)

62. Statista. South Africa - coronavirus (COVID-19) deaths, by age. 2020. https://www.statista.com/ statistics/1127259/coronavirus-covid-19-deaths-by-age-south-africa/ (accessed 14 July 2020).

63. Western Cape Government. Covid-19 dashboard - Covid-19 response. 2020. https://coronavirus westerncape.gov.za/covid-19-dashboard (accessed 6 August 2020).

64. Kirby T. Evidence mounts on the disproportionate effect of COVID-19 on ethnic minorities. Lance Respir Med 2020;8(6):547-548. https://doi.org/10.1016/S2213-2600(20)30228-9

65. Yancy CW. COVID-19 and African Americans. JAMA 2020;323(19):1891. https://doi.org/10.1001/ jama. 2020.6548

66. Hall K, Sambu W. Income poverty, unemployment and social grants. S Afr Child Gauge Child Fam State 2018;27(1):137-143

67. AVERT. HIV and AIDS in South Africa. 2020. https://www.avert.org/professionals/hiv-around-world/ sub-saharan-africa/south-africa (accessed 5 August 2020).

68. Goga A, Chirinda W, Ngandu NK, et al. Closing the gaps to eliminate mother-to-child transmission of HIV (MTCT) in South Africa: Understanding MTCT case rates, factors that hinder the monitoring and attainment of targets, and potential game changers. S Afr Med J 2018;108(3a):s17-s24. https://doi. org/10.7196/SAMJ.2017.v108i3b.12817

69. Li H, Yu G, Duan H, Fu J, Shu Q. Children's healthcare visits during COVID-19 pandemic in Hangzhou, China. J Pediatr 2020. https://doi.org/10.1016/j.jpeds.2020.05.013

70. Fore HH. A wake-up call: COVID-19 and its impact on children's health and wellbeing. Lancet Glob Health 2020;(20):19-20. https://doi.org/10.1016/S2214-109X(20)30238-2 